\title{
Kernel-based learning control for iteration-varying tasks applied to a printer with friction
}

\section{Citation for published version (APA):}

Poot, M., Portegies, J., \& Oomen, T. (2021). Kernel-based learning control for iteration-varying tasks applied to a printer with friction. 81. Abstract from Benelux Workshop on Systems and Control 2021, Rotterdam, Netherlands.

Document status and date:

Published: 01/01/2021

\section{Document Version:}

Publisher's PDF, also known as Version of Record (includes final page, issue and volume numbers)

\section{Please check the document version of this publication:}

- A submitted manuscript is the version of the article upon submission and before peer-review. There can be important differences between the submitted version and the official published version of record. People interested in the research are advised to contact the author for the final version of the publication, or visit the $\mathrm{DOI}$ to the publisher's website.

- The final author version and the galley proof are versions of the publication after peer review.

- The final published version features the final layout of the paper including the volume, issue and page numbers.

Link to publication

\section{General rights}

Copyright and moral rights for the publications made accessible in the public portal are retained by the authors and/or other copyright owners and it is a condition of accessing publications that users recognise and abide by the legal requirements associated with these rights.

- Users may download and print one copy of any publication from the public portal for the purpose of private study or research.

- You may not further distribute the material or use it for any profit-making activity or commercial gain

- You may freely distribute the URL identifying the publication in the public portal.

If the publication is distributed under the terms of Article 25fa of the Dutch Copyright Act, indicated by the "Taverne" license above, please follow below link for the End User Agreement:

www.tue.nl/taverne

Take down policy

If you believe that this document breaches copyright please contact us at:

openaccess@tue.nl

providing details and we will investigate your claim. 


\title{
Kernel-based learning control for iteration-varying tasks applied to a printer with friction ${ }^{1}$
}

\author{
Maurice Poot ${ }^{2, *}$, Jim Portegies $^{3}$, Tom Oomen ${ }^{2}$ \\ ${ }^{2}$ Control Systems Technology Group, Dept. of Mechanical Engineering, Eindhoven University of Technology, The Netherlands \\ ${ }^{3}$ CASA, Dept. of Mathematics and Computer Science, Eindhoven University of Technology, The Netherlands. * Email: m.m. poot@tue.nl
}

\section{Background}

Feedforward control is essential in mechatronic systems that perform varying motion tasks with extreme accuracy requirements. In $[1,2]$, iterative learning control with polynomial basis functions (ILCBF) is introduced to enable extrapolation of the motion tasks. However, polynomial parameterizations are limited in describing flexible system dynamics, hence do not meet the performance requirements. In [3], identification of inverse non-causal LTI systems using kernels [4] is addressed. However, extensions to nonlinear elements and closed-loop systems are not straightforward.

\section{Problem formulation}

Although developments have been made in iterative learning control for general tasks, at present the use of kernel-based approaches has not been exploited yet. The aim of this research is to develop a kernel-based approach to ILC, and present a specific approach for non-causal and nonlinear basis functions arising in motion feedforward control.

\section{Approach}

The developed kernel-based ILC (KILC) approach exploits the use of non-causal kernels to regularize the non-causal impulse response parameters and learns these simultaneously with prescribed nonlinear basis functions in closedloop. Prior knowledge about the system is added through a developed kernel design approach, which enforces model complexity and non-causality to deal with NMP systems.

\section{Results}

Initial results for positioning of a consumer printer subject to nonlinear friction demonstrate the superior performance of KILC with 201 non-causal impulse response parameters and a non-causal OBF kernel compared to ILCBF with only acceleration as basis. Both methods also have a nonlinear Coulomb friction component. In Fig. 1, the time-domain error and feedforward signals are presented. The results show that KILC automatically identifies impulse response parameters to compensate higher-order dynamics, e.g., the snap parameter.

\footnotetext{
${ }^{1}$ This work is supported by ASM Pacific Technology. The authors thank Dragan Kostić and Robin van Es for their contributions to this research.
}
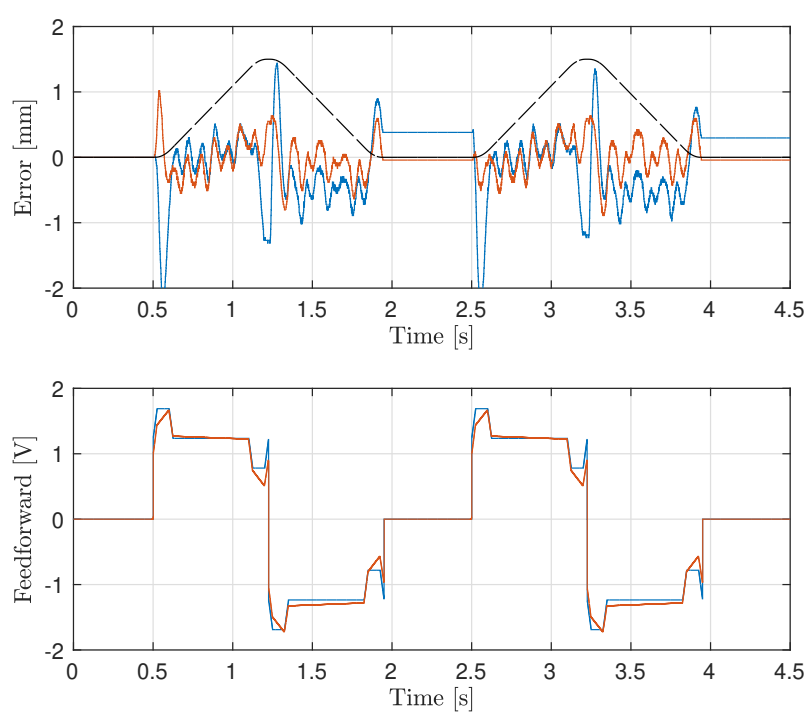

Figure 1: Time-domain error and feedforward signals for the scaled reference (- -) of both ILCBF (-) and KILC using an $\mathrm{OBF}$ kernel (-).

\section{Conclusion and outlook}

The presented KILC framework enables accurate control for a class of non-causal and nonlinear systems. Performance improvements are most prominent for systems with NMP and higher order dynamics. Ongoing research focuses on application to MIMO systems, selecting nonlinear basis functions derived from rigid-body modeling, and modeling position-dependency of the feedforward parameters.

\section{References}

[1] D. Bristow, M. Tharayil, and A. Alleyne, "A survey of iterative learning," EEE Control Syst. Mag., vol. 26, no. 3, pp. 96-114, 2006.

[2] J. Van De Wijdeven and O. H. Bosgra, "Using basis functions in iterative learning control: Analysis and design theory," Int. J. Control, vol. 83, no. 4, pp. 661-675, 2010.

[3] L. Blanken and T. Oomen, "Kernel-based identification of non-causal systems with application to inverse model control," Automatica, vol. 114, p. 108830, apr 2020.

[4] C. Rasmussen and K. Williams, Gaussian Processes for Machine Learning. MIT Press, 2006. 